
\title{
EFFECTS OF Er,Cr:YSGG LASER ON MICROLEAKAGE OF A SELF-ETCH
ADHESIVE SYSTEM
}

\section{ABSTRACT}

Objectives: The purpose of this in-vitro study was to evaluate the microleakage of a self-etch dentin adhesive system in cavities prepared by a conventional dental bur and an Er,Cr:YSGG laser.

Materials and Methods: Forty extracted premolar teeth were selected randomly. Standardized Class V cavity preparations were placed in the buccal and lingual surfaces using a bur and an Er,Cr:YSGG laser. Eighty preparations were randomly assigned to 4 groups of 20 samples each and restored as follows: (G1, Control group) Bur; (G2) Bur + Laser etch; (G3) Er,Cr:YSGG laser; (G4) Er,Cr:YSGG laser + Laser etch. The cavities were restored with a self-etch adhesive system (GC, Unifil Bond) and composite resin (GC, Gradia). The preparations were sectioned buccolingually into three parts and scored for microleakage using a light stereoscope. The data were analyzed with Mann-Whitney U test, and Chi-squared test was used for comparisons across groups.

Results: In all groups, there was higher microleakage in the gingival margin than in the occlusal margin. In the control group (G1), the lowest microleakage values were obtained in all the cavities. In comparison among the groups, statistically significant microleakage values were obtained in the occlusal margins. Significantly high microleakage was observed in G4 in comparison to G1 and G3 ( $p=0.001, p=0.003)$.

Conclusions: Preparation and etching by using an Er,Cr:YSGG laser does not decrease microleakage, but this may also be due to the properties of the self-etch adhesive. Further clinical research and long-term follow-ups are needed to analyze the findings in more detail.

\author{
*Müesser Ahu Durhan ${ }^{1}$ \\ (D) Şirin Güner Onur ${ }^{2}$ \\ (D) Figen Eren Giray ${ }^{1}$ \\ (D) Ilknur Tanboga ${ }^{1}$
}

ORCID IDs of the authors: M.A.D. 0000-0002-0605-1250 Ş.G.O. 0000-0002-6890-3500 F.E.G. 0000-0001-8359-5377 İ.T. 0000-0003-1383-5819

Key Words: Dental adhesives, dental leakage, ysgg laser.

How to Cite: Durhan MA, Onur ŞG, Giray FE, Tanboğa İ. Effects Of Er,Cr:Ysgg Laser on Microleakage of a Self-Etch Adhesive System. Cumhuriyet Dent J 2019;22:2:185191. 


\section{INTRODUCTION}

Microleakage that might occur in the bonding of the tooth-restoration interface is an important factor that affects the lifespan of the restoration. Bonding of the restoration material to the dentine and the enamel has always been an area of interest in dentistry. ${ }^{1}$ In adhesive systems, various classifications were made according to chronological developments or changes in their contents. Van Meerbeek et $a .^{2}$ made a simple classification as total-etch adhesives/self-etch adhesives / glass ionomer adhesives based on the interaction between the adhesive system and the tooth and the number of the steps of application.

For good restoration-tooth bonding, a wellprepared enamel surface morphology is needed. It is known that the efficiency of bonding systems depends on the morphological characteristics and changes on the surface of the teeth. ${ }^{3}$ For this reason, etching with acid and bonding systems has faced several changes in parallel to dentistry material technology which has advanced in time. The steps of etching with acid and rinsing are not applied in self-etch adhesive systems. However, although these systems shorten application time, they still bear several questions about bonding to the dentine and the enamel.

As a result of the developments in laser technology, laser-based practices have become widespread in many areas of dentistry such as diagnosis, preventive dentistry, restorative treatments and endodontic treatments. ${ }^{4}$ As an alternative to conventional treatment methods, which were applied with high-speed and low-speed revolving tools, laser technology has provided an up-to-date approach to removal of caries and preparation of cavities. The use of laser technology is another promising alternative to etching with acid. ${ }^{5}$

Erbium, Chromium: Yttrium, Scandium, Gallium, Garnet (Er,Cr:YSGG), Erbium: YttriumAluminum-Garnet (Er:YAG), Nd:YAG, Diode lasers, Argon lasers and $\mathrm{CO}_{2}$ lasers are the types of laser that are used in dentistry. Er,Cr:YSGG and Er:YAG lasers are preferred in dentistry especially in hard tissues because they provide high absorption with water and hydroxyapatite. They also provide ablation on the enamel and the dentine in an efficient way. It has been demonstrated in previous studies that these surfaces that are exposed to lasers show a characteristically rough surface, are clean and smear-free, have open dentin tubules and enable the dentist to preferably remove the intertubular dentin, which means they have micro irregularities. ${ }^{6,7}$

The purpose of this in-vitro study is to evaluate the efficiency of a self-etch dentin adhesive system in cavity preparation with a conventional dental bur and an Er,Cr:YSGG laser in terms of microleakage.

\section{MATERIALS AND METHODS}

This study forty recently extracted human premolar teeth that were intact and free from caries, restoration, cracks and defects. After extraction, the tissues on the roots were removed with handscaling instruments, and the teeth were cleaned with pumice and stored in a $0.1 \%$ thymol solution for 24 hours.

\section{Cavity Preparation}

Standard Class V cavities with occlusal margin ending at the enamel and gingival margin ending at the cement were prepared using a template on the buccal and lingual surfaces of each tooth. Cavities had a $3 \mathrm{~mm}$ occlusogingival height, $4 \mathrm{~mm}$ mesiodistal length and $2.5 \mathrm{~mm}$ depth at the dentin tissue. The occlusal wall on the enamel was beveled with a $0.5 \mathrm{~mm} 45^{\circ}$ angle. The cement was revealed by removing the whole enamel in the gingival edge of the cavity.

After cavity preparation, the teeth were randomly divided into 4 groups, and each group contained 10 teeth. A total of 80 preparations consisting of 20 samples were randomly assigned to 4 groups and were prepared respectively as follows: Group 1, Control Group (G1) bur, Group 2 (G2) bur+laser etching, Group 3 (G3) Er,Cr: YSGG laser and Group 4 (G4) Er,Cr:YSGG laser + laser etching.

For standardization of the cavities, readymade metal templates were used. In the cavities which were prepared by burs, a diamond bur (ISO 001/018 BR-31 Dia-Scholarship, MANI Inc., Tochigi, Japan) was used for enamel, and carbide bur was used for dentin under water-cooling with a high-speed hand piece. A new bur was used after preparing every 10 cavities.

For cavity preparation/etching with laser, this study used an Er,Cr:YSGG (MillenniumTM, Biolase 
Technology, San Clemente, CA, USA) hydrokinetic laser system with a $2780 \mathrm{~nm}$ wavelength and a 20 $\mathrm{mHz}$ frequency. The laser was applied under the following conditions according to the manufacturer's recommendations: $5.5 \mathrm{~W}$ (85\% water and $85 \%$ air) was used at the enamel and $3 \mathrm{~W}(55 \%$ water and 65\% air) was used at the dentin for cavity preparation, and for surface etching, $1.5 \mathrm{~W}$ (75\% water and $85 \%$ air) was used. In transmission of energy to the surface by a fiberoptic system, a sapphire tip with a $6 \mathrm{~mm}$ length and a $600 \mu \mathrm{m}$ diameter (Biolase-Waterlase) was used. The dimensions of the prepared cavities were approximately the same as the bur-prepared specimens.

After preparation, all cavities were restored with a self-etch bonding agent (Unifil Bond, GC Europe), and a composite resin material (Gradia Direct, GC Europe) according to the manufacturer's instructions (Table 1).

Table 1. Groups

\begin{tabular}{lllll}
\hline Groups & Cavity preparation technique & Surface preparation/Etching & Bonding step & Restoration material \\
\hline Group 1 (G1) & Bur & None & GC Unifill Bond & GC GRADIA \\
\hline Group 2 (G2) & Er,Cr:YSGG laser & None & GC Unifill Bond & GC GRADIA \\
\hline Group 3 (G3) & Bur & Er,Cr:YSGG Laser & GC Unifill Bond & GC GRADIA \\
\hline Group 4 (G4) & Er,Cr:YSGG laser & Er,Cr:YSGG Laser & GC Unifill Bond & GC GRADIA \\
\hline
\end{tabular}

\section{Dye penetration and microleakage measurement}

After the polishing process, the restored teeth were stored in deionized water at $37^{\circ} \mathrm{C}$ for $24 \mathrm{~h}$. The teeth were then subjected to 1000 thermal cycles in water baths at $5-55 \pm 2{ }^{\circ} \mathrm{C}$ with a dwelling time of $30 \mathrm{~s}$ and a transfer time of $3 \mathrm{~s}$. After the thermocycling process, the teeth were stored in distilled water at $37^{\circ} \mathrm{C}$ for $24 \mathrm{~h}$ to prevent dehydration. The apices of the teeth were covered with glass ionomer cement (VOCO- Ionofil Molar AC, Germany). Microleakage was evaluated using a conventional dye penetration method. Each specimen was sealed with two coats of nail varnish leaving a 1-mm window around the cavity margins. The specimens were immersed in $0.5 \%$ of basic fuchsine for $24 \mathrm{~h}$ for dye penetration. The samples were divided into three sections in the buccolingual direction using a slow-speed diamond saw (Isomed 1000 Precision saw, Buehler Ltd, Lake Bluff, IL) mounted in a diamond wafering blade (6" Dia. $\times$ $0.20^{\prime \prime}$ Buehler Ltd) under running water. The digital images were examined by using a stereomicroscope (M80, Leica Microsystems $\mathrm{GmbH}$, Germany) under 10X magnification, and the worst scores for both the occlusal and gingival margins were used for data analyses. The depth of the cavity walls and the length of the microleakage zone $(\mu \mathrm{m})$ along the occlusal and cervical margins were recorded at an accuracy of $0.1 \mathrm{~mm}$ by using a calibrated ocular scale, and the percentage of dye penetration was calculated. The statistical analyses were carried out using the NCSS 2007 and PASS 2008 Statistics Software (Utah, the USA). MannWhitney $U$ test and the Chi-squared tests were applied for comparing the findings among the groups.

\section{RESULTS}

The microleakage scores (percentages, \%) for all four groups at the occlusal and gingival margins are shown in Table 2. Examples of images for the groups are seen in Figures 1-4. The lowest microleakage values were obtained in the Control Group (G1) in the gingival and occlusal margins (Figure 1). In the comparison among the groups, statistically significant differences were found between $\mathrm{G} 1$ and $\mathrm{G} 4 \mathrm{p}=0.001)$ and between $\mathrm{G} 3$ and G4 ( $\mathrm{p}=0.003)$ in terms of their microleakage values in the occlusal margins. No statistically significant differences were found between the microleakage values among the groups in the gingival margins (Table 3).

Table 2. Occlusal and gingival microleakage values in the Groups

\begin{tabular}{|l|l|l|l|l|l|}
\hline Groups & $\mathrm{N}$ & Minimum & Maximum & Mean \pm Std. Deviation \\
\hline \multirow{2}{*}{ G1 (Control group) } & Occlusal & 10 & 0 & 24 & $7.80 \pm 7.510$ \\
\cline { 2 - 6 } & Gingival & 10 & 0 & 50 & $19.80 \pm 17.165$ \\
\hline \multirow{2}{*}{ G2 } & Occlusal & 10 & 0 & 38 & $14.00 \pm 12.875$ \\
\cline { 2 - 6 } & Gingival & 10 & 0 & 47 & $20.00 \pm 13.491$ \\
\hline \multirow{2}{*}{ G3 } & Occlusal & 10 & 0 & 23 & $9.40 \pm 7.633$ \\
\cline { 2 - 6 } & Gingival & 10 & 4 & 50 & $19.40 \pm 15.939$ \\
\hline \multirow{2}{*}{ G4 } & Occlusal & 10 & 10 & 100 & $41.40 \pm 33.417$ \\
\cline { 2 - 6 } & Gingival & 10 & 10 & 100 & $48.90 \pm 33.241$ \\
\hline
\end{tabular}




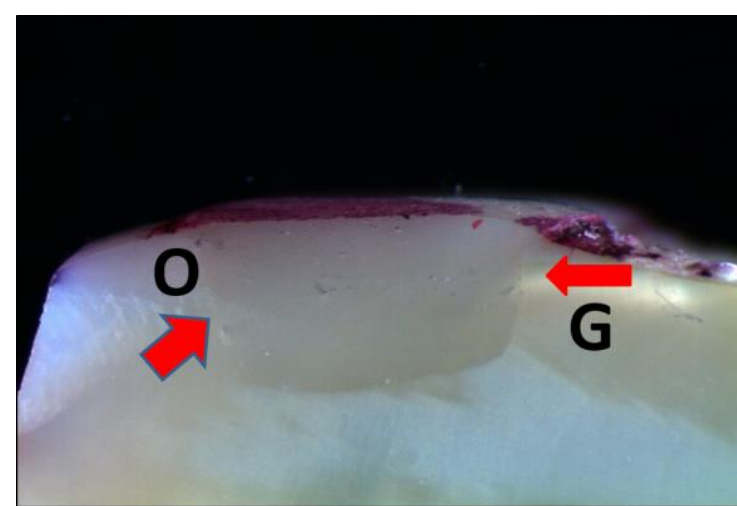

Figure 1. Group 1, Stereomicroscope image

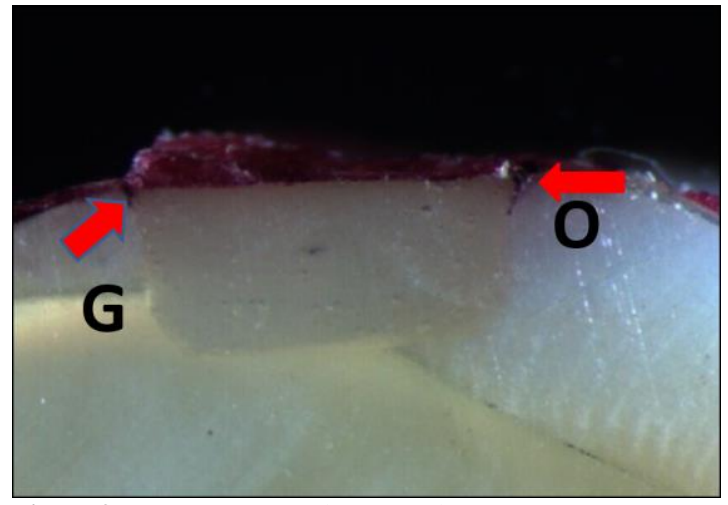

Figure 3. Group 3, Stereomicroscope image

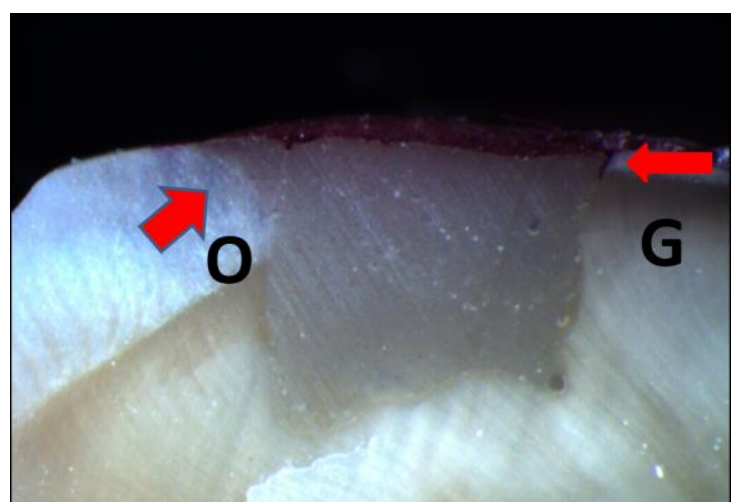

Figure 2. Group 2, Stereomicroscope image

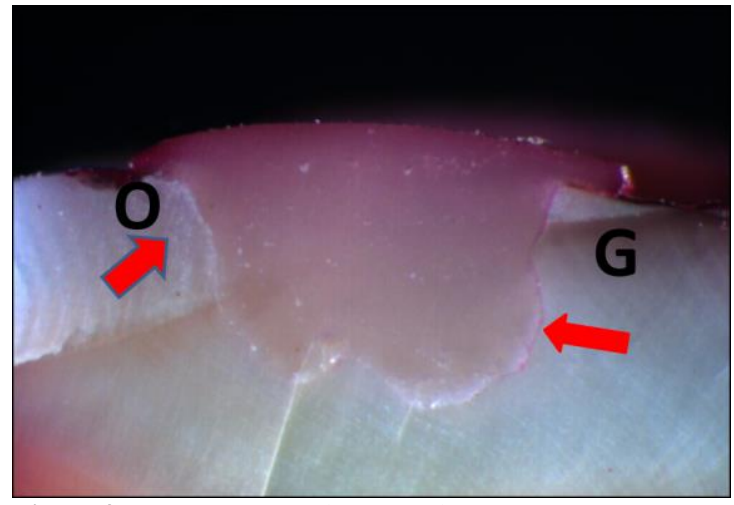

Figure 4. Group 4, Stereomicroscope image

Table 3. Comparison of the Occlusal and Gingival Microleakage Values of the Groups

\begin{tabular}{|c|c|c|c|c|}
\hline & Groups & & $\begin{array}{l}\text { Difference between } \\
\text { means }(\mathrm{I}-\mathrm{II})\end{array}$ & $\mathbf{p}$ \\
\hline \multirow{6}{*}{ 苞 } & \multirow{3}{*}{ Bur (Control group) } & Laser & -6.2 & 0.322 \\
\hline & & Bur + Laser Etching & -1.6 & 0.704 \\
\hline & & Laser + Laser Etching & -33.6 & $0.001 *$ \\
\hline & \multirow{2}{*}{ Laser } & Bur + Laser Etching & 4.6 & 0.469 \\
\hline & & Laser + Laser Etching & -27.4 & 0.037 \\
\hline & Bur + Laser Etching & Laser + Laser Etching & -32.0 & $0.003 *$ \\
\hline \multirow{6}{*}{ 葛 } & \multirow{3}{*}{ Bur (Control group) } & Laser & -0.20 & 0.733 \\
\hline & & Bur + Laser Etching & 0.40 & 0.909 \\
\hline & & Laser + Laser Etching & -29.10 & 0.028 \\
\hline & \multirow{2}{*}{ Laser } & Bur + Laser Etching & 0.60 & 0.570 \\
\hline & & Laser + Laser Etching & -28.90 & 0.028 \\
\hline & Bur + Laser Etching & Laser + Laser Etching & -29.50 & 0.023 \\
\hline
\end{tabular}

\section{DISCUSSION}

It is already known that such leakage occurs especially in Class II and Class V restorations under the enamel-cement junction through the gingival margin. Microleakage that occurs in the cervical areas causes high secondary caries rates, post-operative sensitivity and deterioration of marginal integrity. Consequently, restorations fail under clinical conditions. ${ }^{8}$ It has been aimed to develop cavity preparation and adhesive methods to solve these problems. When they are used with appropriate parameters, dental lasers may be suitable for several functions such as cavity preparation and etching of the enamel and the dentin. The etching stage may support the bonding of restorative material to the surface of the tooth. Previous studies supported the finding that using lasers is more beneficial in comparison to other methods. Additionally, a roughening process with lasers does not have the risks of possible chemical contamination or tissue damage, which are possible in roughening processes that are carried out by using hydrofluoric acid. Considering the advantages of Erbium lasers and self-etch adhesive systems, this study was undertaken to determine whether or not the use of an Er,Cr:YSGG laser would be an alternative to conventional diamond burs in decreasing microleakage for self-etch 
adhesives in Class V cavities. There are some studies which showed that laser etching has higher binding characteristics. ${ }^{910}$ Hossain et al. ${ }^{11}$ reported that enamel and dentin surfaces treated with Er:YAG laser irradiation might reduce the microleakage of restorations that use a composite resin. Kalyoncu et al. ${ }^{12}$ used an Er:YAG laser for cavity preparation and surface alteration in primary molar teeth. They concluded that self-etch bonding systems and cavity preparation with an Er:YAG laser might be used as an alternative to conventional methods.

Microleakage tests are one of the techniques that are commonly used for evaluating the sealing performance of restorative materials and bonding systems. ${ }^{13}$ In recent years, researchers have examined microleakage values following laser applications and compared them to conventional methods. ${ }^{14-16}$ Yamada et al. ${ }^{17}$ conducted a study and evaluated cavities prepared with an Er:YAG laser and those prepared with conventional methods in terms of microleakage, and they reported that there were no statistically significant differences between these methods. In an in vitro study that was conducted by Yazic1 et al. ${ }^{18}$, cavity preparations were carried out with diamond and carbide burs, an Er,Cr:YSGG laser system and chemical vapor deposition. When the enamel and dentin microleakage scores were compared among the groups, no statistically significant differences were observed ( $\mathrm{p}>0.05)$.

In this in vitro study, cavity preparations were carried out on permanent teeth with an $\mathrm{Er}, \mathrm{Cr}$ :YSGG laser, which is becoming common in pediatric dentistry, and with burs. After cavity preparation, the same laser was employed for etching the cavities with the appropriate parameters. The same restorations were applied to the cavities prepared with different methods, and the microleakage values were compared. For Class $\mathrm{V}$ cavities, with the adhesive materials that are employed, lower microleakage values occur with bur-cut surfaces than with surfaces created by use of a laser with additional laser conditioning. The results of our study showed that using Er,Cr:YSGG laser and self-etch adhesive bonding systems together was not successful in comparison to conventional methods.
When caries-affected tissues are removed with a laser, the changes that occur on the surface of the enamel and the dentin might cause differences in the dentin-adhesive bonding process. The changes that occur on the enamel and dentin surfaces are different in comparison to those traditional methods, and these changes may be turned into an advantage in terms of adhesive properties. Shahabi et al. ${ }^{19}$ reported that, after Class V cavity preparation by using an $\mathrm{Er}, \mathrm{Cr}$ : YSGG laser, higher microleakage occurred with phosphoric acid etching of bur- or laser-prepared surfaces than those that occurred with the surfaces created by the use of the laser alone without additional conditioning. The surface energy of the lased surface and the presence of moisture may contribute to optimal wetting induced by using hydrophilic bonding agents. Kohara et al.$^{20}$ reported that there were less marginal microleakages with an Er:YAG laser in comparison to cavities that were prepared with traditional methods. Likewise, Moldes et al. ${ }^{21}$ observed significantly lower microleakage in their Er:YAG and Er,Cr:YSGG lasers and self-etch adhesives groups in comparison to etch and rinse systems.

Aranha et al. $^{22}$ prepared Class $\mathrm{V}$ cavities by using laser-based and traditional methods and evaluated microleakage by applying different adhesive systems. Although there were no statistically significant differences between the different preparation techniques that were employed by the authors, there was a significant difference in the microleakage values between the adhesive systems that were used. ${ }^{23}$ Another factor, which might affect the adhesion of the material based on the adhesive method used on the enamel, is the laser parameters that are used. Ergucu et al. ${ }^{24}$ examined the microleakage values by using singlestep self-etch and total-etch adhesives with burs and different Er:YAG laser parameters in class V cavities. They reported that the laser parameters were effective on microleakage, and higher microleakage was observed in the samples to which the self-etch adhesive was applied in comparison to the total-etch adhesive. They also reported that the best results were obtained with the combination of acid and laser.

Although our findings were consistent with those obtained by previous in vitro studies, higher 
microleakage values were measured in the groups to which the self-etch adhesive was applied following etching with laser in the gingival margins. Different Er,Cr:YSGG laser parameters were not applied the during cavity preparation, and this may be considered as a limitation of our study. Further in vitro and in vivo studies are needed to fully elucidate the effects of laser-based dental studies.

\section{CONCLUSIONS}

Consequently, it was determined that conventional methods yielded more successful outcomes in terms of microleakage. It is considered that, when it is applied alongside self-etch adhesive, etching with a laser technique yields higher microleakage values in the interface between the tooth and the restoration depending on tooth surface characteristics. More clinical studies with longer durations are needed in this respect.

\section{ACKNOWLEDGEMENTS}

None

\section{CONFLICTS OF INTEREST}

All of the authors declare that they have no conflict of interest.

\section{Er,Cr:YSGG Lazerin Self Etch Adeziv Sistemde Mikroslzıntıya Etkisi \\ $\ddot{O} Z$}

Amaç: Bu in-vitro çallş̧manin amacı, geleneksel yöntem ve Er,Cr:YSGG lazer ile hazirlanan kavite preparasyonlarinda; self etch dentin adeziv sisteminin mikrosızıntısı açısından değerlendirilmesidir. Gereç ve Yöntemler: Kırk adet yeni çekilmiş premolar diş rasgele seçildi. Standardize edilmişs Sinıf $V$ kavite preparasyonları frez ve Er,Cr:YSGG lazer kullanılarak bukkal ve lingual yüzeylere hazırlandl. Her biri 20 örnekten oluşan 80 örnek kavite yüzeyi hazırlama yöntemine göre 4 deney grubuna rastgele ayrldd: (G1, Kontrol grubu) Frez; (G2) Frez + Lazer Pürüzlendirme; (G3) Er,Cr:YSGG lazer; (G4) Er,Cr:YSGG lazer + Lazer Pürüzlendirme. Ardindan tüm kavitelere self etch adeziv bonding ajanı (GC, Unifil Bond) uygulanarak kompozit rezin (GC, Gradia) ile restore edildi. Örnekler bukko-lingual yönde üçe bölündü ve ışık mikroskobu altında incelenerek, mikro-sızıntı açısından skorlandı. Elde edilen veriler NCSS 2007 ve PASS 2008 Istatistik Yazılımı (Utah, ABD) ile analiz edildi. Gruplar arasinda bulguları karşılaştırırken Mann Whitney U testi, ki-kare testi uygulandl. Bulgular: Tüm gruplarda gingival marjinde, okluzal marjine göre daha yüksek mikrosizıntı bulundu. Kontrol grubunda (G1) tüm kavitelerde en düşük mikrosızintı değerleri elde edildi. Gruplar arasındaki karşılaştırmalarda; okluzal marjinlerde mikrosızıntı açısından istatistiksel olarak anlamlı değerler elde edildi. G4'de, G'e ve G3'e göre istatistiksel olarak anlaml düzeyde daha yüksek mikrosızıntı değerleri gözlendi ( $p=0,001, p=0,003)$. Sonuçlar: Bulgulara göre; Er,Cr:YSGG lazerle preparasyon ve pürüzlendirme işleminin mikrosızlnttyı azaltmadı̆̆ ancak bunun self etch adeziv sistemlerin özelliklerinden de kaynaklanabileceği belirlenmiştir. Bulguları analiz etmek için daha ileri klinik araştırmalar ve uzun vadeli takip gereklidir.

Anahtar Kelimeler: Dental adezivler, dental sizintt, ysgg lazer.

\section{REFERENCES}

1. Gupta A, Tavane P, Gupta PK, Tejolatha B, Lakhani AA, Tiwari R, Kashyap S, Garg G. Evaluation of Microleakage with Total Etch, Self Etch and Universal Adhesive Systems in Class V Restorations: An In vitro Study. J Clin Diagn Res 2017;11:ZC53-ZC56.

2. Van Meerbeek B, De Munck J, Yoshida Y, Inoue S, Vargas M, Vijay P, Van Landuyt K, Lambrechts P, Vanherle G. Buonocore memorial lecture. Adhesion to enamel and dentin: current status and future challenges. Oper Dent 2003;28:215-235.

3. Ayar MK. Evaluation of resin-enamel interface micromorphology in respect of different Er,Cr:YSGG laser parameters. Photon Lasers Med 2014.

4. Bahrololoomi Z, Heydari E. Assessment of Tooth Preparation via Er:YAG Laser and Bur on Microleakage of Dentin Adhesives. J Dent (Tehran) 2014;11:172-178.

5. Lopes RM, Trevelin LT, da Cunha SR, de Oliveira RF, de Andrade Salgado DM, de Freitas PM, de Paula Eduardo C, Aranha AC. Dental Adhesion to ErbiumLased Tooth Structure: A Review of the Literature. Photomed Laser Surg 2015;33:393-403.

6. Eren Giray F, Duzdar L, Oksuz M, Tanboga I. Evaluation of the bond strength of resin cements used to lute ceramics on laser-etched dentin. Photomed Laser Surg 2014;32:413-421.

7. Tachibana A, Marques MM, Soler JM, Matos AB. Erbium, chromium:yttrium scandium gallium garnet laser for caries removal: influence on bonding of a self-etching adhesive system. Lasers Med Sci 2008;23:435-441. 
8. Peskersoy C, Yildirim G, Ozata F, Onal B. Üç Farklı Akışkan Kompozitin ve Bir Kendinden Adezivli Akışkan Kompozitin Sınıf V Restorasyonlardaki Mikrosızıntı Değerlerinin İn-vitro Olarak İncelenmesi EÜ Diş Hek Fak Derg 2013;34:99-104.

9. Hosseini MH, Sobouti F, Etemadi A, Chiniforush N, Shariati M. Shear bond strength of metal brackets to feldspathic porcelain treated by Nd:YAG laser and hydrofluoric acid. Lasers Med Sci 2015;30:837-841.

10. Cavalcanti BN, Lage-Marques JL, Rode SM. Pulpal temperature increases with Er:YAG laser and highspeed handpieces. J Prosthet Dent 2003;90:447-451.

11. Hossain M, Yamada Y, Nakamura Y, Murakami Y, Tamaki Y, Matsumoto K. A study on surface roughness and microleakage test in cavities prepared by Er:YAG laser irradiation and etched bur cavities. Lasers Med Sci 2003;18:25-31.

12. Kalyoncu IO, Eren-Giray F, Huroglu N, Egil E, Tanboga I. Microleakage of Different Adhesive Systems in Primary Molars Prepared by Er: YAG Laser or bur. Niger J Clin Pract 2018;21:242-247.

13. Gungor HC, Canoglu E, Cehreli ZC. The effects of dentin adhesives and liner materials on the microleakage of class II resin composite restorations in primary and permanent teeth. J Clin Pediatr Dent 2014;38:223-228.

14. Synarellis A KP, Koulaouzidou E, Strakas D, Koliniotou-Koumpia E. In Vitro Microleakage of class V Composite Restorations prepared by Er,Cr:YSGG Laser and Carbide BUR. BJDM 2017;21:24-31.

15. Subramaniam P, Pandey A. Assessment of Microleakage of a Composite Resin Restoration in Primary Teeth Following Class III Cavity Preparation Using Er, Cr: YSGG laser: An In Vitro Study. J Lasers Med Sci 2016;7:172-176.

16. Jhingan P, Sachdev V, Sandhu M, Sharma K. Shear Bond Strength of Self-etching Adhesives to Cavities Prepared by Diamond Bur or Er,Cr:YSGG Laser and Effect of Prior Acid Etching. J Adhes Dent 2015;17:505-512.
17. Yamada Y, Hossain M, Nakamura Y, Murakami Y, Matsumoto K. Microleakage of composite resin restoration in cavities prepared by Er:YAG laser irradiation in primary teeth. Eur $\mathrm{J}$ Paediatr Dent 2002;3:39-45.

18. Yazici AR, Yildirim Z, Antonson SA, Kilinc E, Koch D, Antonson DE, Dayangac B, Ozgunaltay G. Comparison of the Er,Cr:YSGG laser with a chemical vapour deposition bur and conventional techniques for cavity preparation: a microleakage study. Lasers Med Sci 2012;27:23-29.

19. Shahabi S, Ebrahimpour L, Walsh LJ. Microleakage of composite resin restorations in cervical cavities prepared by Er,Cr:YSGG laser radiation. Aust Dent J 2008;53:172-175.

20. Kohara EK, Hossain M, Kimura Y, Matsumoto K, Inoue M, Sasa R. Morphological and microleakage studies of the cavities prepared by Er:YAG laser irradiation in primary teeth. J Clin Laser Med Surg 2002;20:141-147.

21. Moldes VL, Capp CI, Navarro RS, Matos AB, Youssef $\mathrm{MN}$, Cassoni A. In vitro microleakage of composite restorations prepared by Er:YAG/Er,Cr: YSGG lasers and conventional drills associated with two adhesive systems. J Adhes Dent 2009;11:221-229.

22. Aranha AC, De Paula Eduardo C, Gutknecht N, Marques MM, Ramalho KM, Apel C. Analysis of the interfacial micromorphology of adhesive systems in cavities prepared with Er,Cr:YSGG, Er:YAG laser and bur. Microsc Res Tech 2007;70:745-751.

23. Aranha AC, Turbino ML, Powell GL, Eduardo Cde P. Assessing microleakage of class $\mathrm{V}$ resin composite restorations after Er:YAG laser and bur preparation. Lasers Surg Med 2005;37:172-177.

24. Ergucu Z, Celik EU, Turkun M. Microleakage study of different adhesive systems in Class $\mathrm{V}$ cavities prepared by Er,Cr:YSGG laser and bur preparation. Gen Dent 2007;55:27-32. 